\title{
Contextualizing the Identity Development of Preservice Elementary Mathematics Teachers in Methods Courses and Mentor Teacher Support
}

\author{
Hyun Jung Kang ${ }^{1} \&$ Dan Battey ${ }^{2}$ \\ ${ }^{1}$ School of Teacher Education, University of Northern Colorado, Colorado, United States of America \\ ${ }^{2}$ Graduate School of Education, Rutgers University, New Jersey, United States of America \\ Correspondence: Hyun Jung Kang, School of Teacher Education, University of Northern Colrado, 50120 th Street, \\ Greeley, CO 80639, USA. Tel: 1-970-351-2760.
}

Received: November 1, 2017

Accepted: November 29, $2017 \quad$ Online Published: December 14, 2017

doi:10.20849/jed.v1i1.248

URL: https://doi.org/10.20849/jed.v1i1.248

\begin{abstract}
Drawing on a situative perspective, this study explores how preservice elementary teachers develop themselves as teachers of mathematics and critical experiences in their identity development, in particular, from teacher education coursework through their student teaching experiences. Through two cases, this study reveals that mentor relationships were critical in shaping preservice teachers' identities as mathematics teachers and in building their initial mathematics teaching practices. Findings suggest that successful mentoring is necessary, and this generally requires sharing common goals, receiving feedback, and having opportunities to practice knowledge, skills, and identities on the part of beginning teachers. This study adds to the field of teacher education research by focusing on prospective teachers' identity constructions in relation to their communities of practice, and also by emphasizing the role of mentors in preservice teachers' identity development.
\end{abstract}

Keywords: elementary preservice teacher, mathematics education, teacher identity, mentor relationship, teacher education

\section{Introduction}

The term identity is prominent in the field of education (Sfard \& Prusak, 2005). Sumara \& Luce-Kapler (1996) emphasize the long-term characteristics of teacher learning using the concept of identity. They document that beginning teachers must negotiate multiple teacher identities. This development includes the identities that preservice teachers bring with them into teacher education as well as their learning during the teacher education program, both of which contribute to their transition into the profession of teaching. Central to preservice teachers' identity development are university coursework and the student-teaching practicum, which can be their first practice-based connection to school environments. Due to these multiple contexts and on-going learning experiences, this study focuses on preservice teachers' identity development to explore how they become teachers drawing on a situative perspective (Lave \& Wenger, 1991). Lave and Wenger characterize the learning of practices as a process of participation in a community that works together. This theoretical framework allowed us to better understand the process of learning to teach mathematics as an on-going process through the lens of identity development. We also use identity development as a critical lens because teacher identities are important in order to understand teacher learning and teacher practice. However, identity is rarely analyzed as a direct link to teacher practice (Enyedy, Goldenberg, \& Welsh, 2005). Within this framework, we detail the identity development of two preservice elementary teachers across mathematics methods and the student teaching experience to better understand how it shifted as they engage within these programs, which served as a community of practice.

In responding to the research questions below, we hope to shed light on this important process of learning to teach by raising the complexities and nuances in the identity development of elementary mathematics teachers. Further, the analyses illuminate a number of potential factors of identity development and implications for teacher educators to better support preservice teachers.

(1) How do aspiring elementary teachers construct their professional identity during the critical periods of mathematics methods coursework and student teaching? 
(2) What are the critical factors that contribute to the construction of their identity?

\section{Literature Review and Theoretical Background}

To explore the complexity of identity, we begin by describing the identity lens used in this work followed by a review of literature specifically on mathematics teacher identity.

\subsection{Theory: Framework of Identity Development}

In terms of teacher identity, we draw on Wenger's (1998) notion of identity for two reasons- the connection between the individual and social and identity as an on-going process. Wenger (1998) states that identity is related to one's personal history and emphasizes the importance of social context. How a teacher experiences her job, how she interprets her position, and what she understands about what she does are not only related with her personal history, but also connected with the community in which she belongs. From Wenger's perspective, "identity is shaped by belonging in a community but with a unique identity" (p. 146), which means one's identity is defined socially. Similarly, Kilgore (1990) addresses the importance of the connection between the individual and the social. Her research addresses how individual teachers play an active role in deciding what kind of teacher they want to be, but their agency is limited within their given social contexts. Therefore, it is necessary to investigate both the individual's learning process and the given culture to more fully describe the complexity of learning to teach. Another important idea is Wenger's focus on identity as a trajectory, "we define who we are by where we have been and where we are going" (p. 149). Drawing on the work of Wenger, we define teacher identity as how a mathematics teacher views themselves in relation to his/her prior experience, to his/her teacher education program, and to his/her students in the classroom.

The other key concept of identity is that identity development is an on-going process. Wenger (1998) views identity as a negotiated practice, which means it is a process of becoming who we are through negotiation through participation and reification. Holland and Lave (2001) add that identity is constantly created and re-created in interactions between people. The study of Horn, Nolen, Ward and Campbell (2008) adopt Wenger's notion of identity and explore how preservice teachers modified their mathematics teaching identities during their teacher education program. Through participating in coursework and engaging with the community, preservice teachers negotiated what to adopt and what to reject in teaching mathematics. This resulted in a newly negotiated teacher identity that developed built from their entering identities. The on-going process of identity development is important because this study focuses on how preservice teachers develop their identities continuously within a community of practice over time.

This notion of identity development implies that teacher identity is socially constructed while serving as an agent who constantly makes instructional decisions within the community. For instance, during the teacher education program, preservice teachers continue a process of identify development through interaction with methods instructors and mentor teachers as they identify what is important in teaching mathematics and the goal for student learning in mathematics. In this way, to understand teacher identity, it is critical to examine preservice teachers' prior beliefs, knowledge, and experience with mathematics through the lens of individual agency, but also to explore the community where preservice teachers belong, such as methods coursework and student teaching placements.

\subsection{Identity Development of Preservice Mathematics Teachers}

For preservice teachers, the focus of teacher identity is placed on developing of identity emerging in relationships and on its exploration of the influence on the identity development (Hamman, Gosselin, Bomano, \& Bunuan, 2010). This section reports first how literature discuss preservice teachers' identity development and its contributing factors will be followed by. As an example of identity development, researchers describe the typical identity development as that preservice teachers bring traditional mathematics teacher identities based on their earlier experience, and they encountered reform-based teaching mathematics identity during various teacher education programs (Cady, Meier, \& Lubinski, 2006; Ebby, 1999). Thus, depending on the context around preservice teachers, the identity development looks very different. For example, in the study of Ebby (1999), preservice teachers were engaged with constructivist identity during teacher preparation courses. However, some preservice teachers developed mathematics teacher identity as constructivist but some did not. She confirmed that whether or not the preservice teachers adopt the constructivist identity for their own mathematics, teaching practices has much to do with their prior beliefs, dispositions, and experiences that they bring with them. She concluded that to implement the new model of teaching emphasized by the methods courses, the goal of the courses should be on developing a self-image and identity as learners. 
Similarly, Eisenhart and Borko (1992) conducted a case study of one teacher, Ms. Daniel during her student teaching. They explored Ms. Daniel's identity development as a reform-based mathematics teacher because she learned that pedagogy from her methods class. However, Ms. Daniel's identity as reform-based mathematics teacher was not reinforced much because of unsupportive school settings and lack of mentor's support. On the other hand, Steele's (2001) case study described the characteristics of teachers who were able to develop mathematics teacher identity based on reform-based teaching pedagogy. Mary and Vanessa, the two preservice teachers who sustained new ways of teaching mathematics, were able to develop reform-based teacher identity because of variety of reasons such as school setting, curriculum and interpretation of test pressure. These case studies demonstrate the typical identity development trajectory as preservice teachers but they also shows that the reason varies depending on the situation. Due to this complexity, Hamman et al. (2010) report that it is useful to explore identity formational process to chart proximity to more mature development.

\subsection{Contributing Factors to Identity Development}

We stated prior that identity development is an important lens because it engages with both individual and social factors. On the individual level, looking at the development of teacher identity helps us to understand how preservice teachers learn to teach mathematics in terms of their beliefs, knowledge, and relationships. On the social level, examining teachers' identity development helps us to understand how preservice teachers adjust to their mentor teacher and school contexts because identity is continuously negotiated and constructed in relation to the community of practice in which they belong (Wenger, 1998). Thus, it is critical to explore preservice teachers' individual experiences and their social context to better understand the impact on identity development. To illustrate this, we first document ways that the current literature addresses the role of individual factors on identity development before addressing the impact of social factors.

For individual factors, scholars have reported preservice teachers' experiences prior to the teacher education program influenced their mathematics identities. For instance, based on preservice teachers' K-12 school experiences, teachers' relationship with mathematics has been found to often be fraught with anxiety (Hodgen \& Askew, 2007) and traditional, viewing mathematics as rule bound, based on drill-and-practice, and focused on finding answers (Cady et al., 2006; McDiarmid, 1990). These studies raise the need to consider that preservice teachers bring their incoming identities as traditional mathematics teachers to teacher education programs due to prior beliefs, attitudes, and knowledge. Thus, they must negotiate in order to integrate new knowledge and practices that the program offers with their incoming identities. Thus K-12 school experiences are an important factor in constructing preservice teachers' incoming identities.

When considering identity as a social process, it is also important to consider factors other than prior schooling that influence preservice teachers' identity construction. Drake, Spillane, and Hufferd-Ackle (2001) state that teacher identity construction is linked to teacher knowledge and beliefs with sociological constructs of practice. This means that teachers' personal beliefs and knowledge are factors that shape teacher identities, however, we must also look at the social environment influencing teachers' knowledge and beliefs. Enyedy et al. (2005) build on Drake et al. concepts, documenting that teachers' social environment includes relationships to students, classroom communities, and school administrations and that institutional relationships are important factors that shape a person's identity and practice.

One significant social factor is student teaching because preservice teachers seek to confirm their self-image as teachers separate from their previous image as students (Bullough, 1992), and they experience an exemplar of "good" teaching from their mentor (Feiman-Nemser, 2001) that influences their teaching practice. Other studies emphasize that having a clear self-image as a teacher is critical for translating what has been learned from the teacher education program into fully realized classroom practices (Bullough, 1992; Kagan 1992; Mewborn, 1999). These studies document that preservice teachers struggle with their teaching practices when they don't have secure self-images as teachers, even though they had support from both the university and mentor teachers in coherent ways. Whether they see themselves as a traditional mathematics teacher (image from early student experiences) or a new-model teacher (provided by the teacher education program), their teaching practices look fundamentally different. These studies raise the importance of context in identity development in building a self-image of a teacher.

Another line of research conceptualizes the student teaching experience as an influential factor due to mentor teachers (Hawkey, 1998; Wang \& Odell, 2007). Hawkey (1998) reports that regardless of mentoring style, the mentor's perspective of learning to teach was an influential factor in preservice teachers' initial teaching practice. Wang and Odell (2007) state that preservice teachers tend to emulate mentor teachers' teaching practice. However, these studies do not address how the mentor relationship influences preservice teacher's mathematics 
teaching practice. To explore this particular relationship, this study draws on the apprenticeship model (Lave \& Wenger, 1991) connecting to Wegner's notion of identity. Apprenticeship frames mentor teachers as masters who are full members of the community and understand the dynamics of the community. Meanwhile, the preservice teacher is a novice who is a peripheral member of the community, but is developing an "identity of mastery" through participation in student teaching. This process, also called "legitimate peripheral participation," involves beginners who are peripheral in the community of practice, but as novices gain experience, they move to more central and sophisticated participation. Lave and Wenger (1991) also emphasize how an apprentice's identity derives from the process of becoming part of the community of practice. From this point of view, a preservice teachers' identity is developed in the community where they find themselves (e.g., the methods classroom, student teaching) in relation to the goals of the community and how they adapt themselves to the goals of the given social context. Consequently, it is important to explore how the preservice teachers participate in the community of practice and how they engage with their mentor teachers to develop their knowledge and skills.

Taken together, this study attempts to shed light on the important relationship between preservice teachers and mentors, as one social factor that influences teacher identity and a preservice teachers' initial mathematics teaching practice.

\section{Methodology}

This study used multiple case study methods (Yin, 1995) to understand the identity development of preservice teachers across methods coursework and student teaching. Case study methods were useful because we wanted to understand the complex dynamics of identities rather than generalizing to a population. The data were collected during two consecutive semesters: one 16-week semester of a mathematics methods class and another 16-week semester of student teaching experience. The participants are two elementary preservice teachers and their mentor teachers. The major data sources for this study were weekly classroom observations and multiple in-depth interviews.

\subsection{Participants}

The participants were two preservice teachers, seniors in the teacher education program, at a large university located in the southwest United States. The teacher preparation program required them to take 9 credits of college mathematics prior to, and a mathematics methods class during, their fourth year in the elementary program. After the methods class, preservice teachers were placed in local elementary schools to student teach. During the 16-week mathematics methods course, the authors observed every week (three hours per session) for the entire class period and took field notes on how the preservice teachers interacted with peers, how they shared their mathematical thinking, and how they participated in class activities. Two selection criteria were used-one was the confidence level of preservice teachers and gaining access to both the local schools and their mentor teachers.

Based on these criteria, two preservice teachers and their mentor teachers-Jackie and Mr. Brown \& Meg and Mrs. Green (Note 1) were selected. Table 1 below provides background on the participants. The interview about participant's prior mathematics experiences before the teacher education program demonstrated quite different experiences - positive vs. negative - and we sought to investigate how these contrasting incoming identities would play out during their student teaching experience. 
Table 1 . Summary of participants

\begin{tabular}{lcc}
\hline & Jackie & Meg \\
\hline $\begin{array}{l}\text { Preservice } \\
\text { Teachers }\end{array}$ & White female & White female \\
& Senior, Elementary program & Senior, Elementary Program \\
& Not confident with mathematics & Very confident with mathematics \\
Mentor & 5th grade (10-11 years old) & Mrs. Green \\
Teachers & White male & 2nd-3rd combination class (7-9 years old) \\
& 11 year experience & White female \\
& Confident in teaching mathematics & Not confident teaching mathematics \\
School & J Elementary School & R Elementary School \\
Description & $86.5 \%$ of students scored proficient or & $75.6 \%$ of students scored proficient or \\
& higher in mathematics & higher in mathematics
\end{tabular}

\subsection{Data Collection}

The data sources for this study were interviews at multiple time points and weekly classroom observations, both in the methods course and the mentor teachers' classrooms. Table 2 shows a schedule of data collection. We detail each of the data sources below.

Table 2. Schedule of data collection

\begin{tabular}{lcc}
\hline Time of the year & Data Source & Duration \\
\hline $\begin{array}{l}\text { Methods class } \\
\text { (including 72 hour of } \\
\text { internship) }\end{array}$ & Observation & Once/week \\
& & 3 hours/week \\
& & 15 weeks \\
1st preservice teacher interview & End of semester \\
Student teaching & Approx. 30 minutes \\
(Following semester) & Once/week \\
& & Total 11 weeks \\
& 2nd preservice teacher interview & Approx. 40 minutes \\
& & Middle of semester \\
& Mentor teacher interview & End of semester \\
& & Approx. 30 minutes \\
\hline
\end{tabular}

Methods Class Observations. The methods course was observed to explore the models of mathematics teaching made available to the preservice teachers as well as the types of identities they were supported in developing. During this course, the preservice teachers were engaged with a reform model of teaching mathematics that focuses on developing students' thinking, orchestrating mathematical discussions, supporting multiple strategy use, and justifying answers (e.g., Senk \& Thompson, 2003). The methods course instructor, Ms. P., consistently asked preservice teachers conceptual questions about the mathematics content and to justify their mathematical thinking. During observations, we looked for evidence of participants' knowledge of mathematics, what they thought was important mathematically, and what they knew about teaching mathematics. This supported case selection and analysis in understanding the identities participants were developing in the course. We also considered that when preservice teachers publically stated their opinion that this was evidence of their confidence. We did this because confidence is related to their ability to learn and teach mathematics (Graven, 
2004). Observation field notes were taken every week and used to purposively select highly engaged preservice teachers with different levels of confidence in mathematics.

Student Teaching Observations. During preservice teachers' student teaching, a weekly classroom observation was conducted. Classroom observations focused on three areas: 1) the relationship between the model of mathematics instruction to the mathematics methods course (e.g., the available models of becoming a mathematics teacher), 2) the relationship between mentor teachers and preservice teachers, including the degree of participation of the preservice teacher, and 3) the structure of feedback or comments provided to preservice teachers (e.g., the support provided for becoming a certain kind of mathematics teacher). These provided the background needed to capture the teachers' emerging identities and instructional practices. This also allowed a comparison of instructional methods during the methods course with student teaching in order to make assertions regarding differences and similarities. All classroom observations were recorded in detailed written field notes.

Interviews. Interviews provided an opportunity to gather evidence concerning teachers' identities, knowledge, and beliefs about teaching mathematics. Since identity development is an ongoing process (Holland, Lachicotte, Skinner, \& Cain, 1998), interviews at different time periods allowed us to obtain: 1) participants' varying interpretations of their experiences, 2) their understanding of the context in which they worked, and 3) personal knowledge and beliefs about mathematics teaching practices in relation to their identities. Multiple interviews enabled us to see how preservice teachers' identities developed or changed and the possible interpretations embedded in such change. All interviews were semi-structured, audio recorded, and transcribed verbatim.

\subsection{Analysis}

Pattern coding, from Miles and Huberman (1994), was used to analyze the data. First, the authors carefully read through all field notes and interview transcripts within the cases in search of emerging themes or patterns, categorizing them in chronological order. While repeating this process, we noted evidence of identity statements from interview transcripts and analyzed observed behaviors as enacted identities.

Regarding identity statements, we considered three characteristics. First, drawing on Drake (2006), who states that one's personal story is part of one's identity, we looked for the preservice teachers' descriptions of their personal experiences with mathematics or mathematics teachers as evidence of their incoming identities while analyzing the preservice teachers' K-12 school experiences. Secondly, we searched interview statements about preferences and beliefs because these influence behavioral decisions about how to enact one's identity. For example, as a part of her identity, one student teacher believed that hands-on activities were the best way to teach mathematics because she had a good experience with this in a high school geometry class. She also enjoyed learning mathematics with hands-on activities during her mathematics methods class. Lastly, statements used for evidence of designated identity were descriptions of being a teacher. For instance, "I want to be a teacher who teaches math...", "My goal as a teacher is to...", "I want to teach like Ms. P.", and "When I have the opportunity to teach, I want to...". With respect to enacting identity, we looked at their discourse and actions, such as the questions they asked, the problems they posed, and what materials they used to teach mathematics. This process allowed us to be able to characterize preservice teacher's identity before and during the methods course, as well as their enacted identity in student teaching. Also, we were able to directly analyze how this identity was reinforced or suppressed as preservice teachers participated in the methods course and their mentor teacher's classroom. This process helped us to identify the particular events or experiences that contributed to identity construction.

Validity was addressed through triangulation of data sources, sequential collection of data, use of two independent coders, and member checking. The analysis of observational field notes, preservice interviews, and mentor interviews provided overlapping evidence of preservice teachers' identities. Therefore, multiple data sources were used in triangulating assertions from the analysis. Additionally, data collection was sequential allowing for prior analysis to inform and confirm/disconfirm subsequent data collection. For example, observations of the methods course allowed for specific questioning of student behaviors to better understand their participation, confidence, knowledge, and developing identity. Likewise, the mentor teacher interview served as a final check of both the student teacher observations and the second preservice teacher interview.

\section{Results}

Below, the authors present findings of the cases of Jackie and Meg separately. Drawing on Wenger's (1998) notion of identity as constantly becoming, each case is organized in chronological order-incoming identity, designated identity, and actual identity. Each case shows how they developed their identity as mathematics teachers over time and how this development related to their experiences across multiple settings, including mathematics experiences, the mathematics methods class, and student teaching. This structure offers a detailed 
picture of identity development and the specific events or experiences that emerged across settings.

\subsection{Jackie's Identity}

\subsubsection{Jackie's Incoming Identity Brought to Mathematics Methods Course}

"Mathematics is not fun" was a common statement from Jackie when asked about her K-12 experiences with mathematics. Jackie remembered that mathematics had not been her favorite subject. She expressed negative views of mathematics several times during the interview, stating that she never really liked mathematics because she was never good at it. Jackie's lack of confidence and unpleasant learning experience in mathematics continued until she took the mathematics methods course.

She reflected that this course challenged her mostly negative incoming identities to positive ways because it was a totally new experience of teaching mathematics. Jackie stated that the mathematics methods taught in the class were very different from the way she was taught as a child.

I would say it is very different than when I was growing up. I would say the biggest thing I applied from the methods course was the fact that Ms. P. [methods course instructor] stressed using manipulations so much. Every day we did hands-on mathematics, the thing that I didn't even think we can do or use manipulations, we were using it. The class was three hours long but I felt like it went by very quickly and that is how I knew it was a very good class. (Jackie's 1st interview)

For Jackie, the emphasis on manipulations was a critical development in learning how to teach mathematics. Additionally, manipulative use was a part of her geometry learning experience-Jackie's only positive relationship with mathematics during K-12 schooling. Before taking the mathematics methods course at the university, Jackie viewed mathematics as boring, not practical, and hard to understand. She stated that she was worried about teaching mathematics mostly because she thought she had to remember everything and memorize the steps of solving problems. However, while taking the methods class, Jackie experienced new knowledge and skills to practice teaching mathematics, and she began to realize mathematics could be taught differently, in a fun way. This communicates another central aspect to Jackie's emerging identity as a mathematics teacher; the intention to make mathematics fun.

When I was growing up I very rarely used manipulations in class. It was very much like, here are the examples on the overhead and here is the worksheet. I think a lot of teachers teach that way. It wasn't necessarily bad, but it just wasn't as fun. (Jackie's 1st interview)

One possible reason why she seemed to look for fun in learning mathematics is due to her own lack of enjoyment when she learned mathematics as a student. Here we see a shift in her identity through the new knowledge gained from the methods course with the intention of making mathematics fun.

While we see new knowledge forming for Jackie about methods to teach mathematics that contrast with her K-12 student experience, it is clear that making mathematics fun and using manipulations as tools are integral parts of Jackie's identity as a mathematics teacher. At the end of the methods course, Jackie expressed a strong identity statement about what kind of mathematics teacher she wanted to be.

I believe children learn the best with hands on, anytime they can do hands on, that is one of the best ways. Whole-group participation on the white board or telling me the answers to the problem, or working this out, those are also great assessment but when students can participate as a class and also get their hands involved, kids will do better on by themselves, and work on their space. I think it is really beneficial when they can do hands-on but I think most of them, hands-on are the best. (Jackie's 1st Interview)

While placing value in teaching mathematics with hands-on activities and making math fun, Jackie started her student teaching the following semester.

\subsubsection{Student Teaching: Jackie's Emerging Identity in the Community of Practice}

Jackie student taught in Mr. Brown's classroom. Mr. Brown was a veteran 5th grade teacher who had been teaching for 11 years. Jackie wanted to practice her emerging identity based on new knowledge and skills gained from the mathematics methods course to become a fun mathematics teacher. However, the analysis of interviews, and observations indicated that Jackie's incoming identity was not reinforced in this community of practice. Jackie's emerging identity, a fun mathematics teacher who teaches mathematics with hands-on activities, was not fully realized as we document below.

As a novice teacher, Jackie started developing her teaching practice by adopting the structure of her mentor's lessons. As the semester went on, Jackie took over some of the simple tasks of the mathematics lessons such as collecting homework, checking answers, preparing materials, and walking around the classroom to support 
students. Compared to other subject areas, Jackie's participation as a fun mathematics teacher remained peripheral throughout the semester, mainly due to her low confidence in mathematics and lack of time practicing teaching.

However, there is evidence that Jackie attempted to teach mathematics in a fun way, in alignment with her stated identity. When she had to teach a probability lesson, she used M \& Ms and told the class that she wanted to do the lesson with M \& Ms because she thought it was going to be fun. Yet, the lesson was not successful because the lack of detailed directions confused students and Jackie had difficulty connecting the activity to important concepts of probability. Even though the overall experience of the math methods class allowed Jackie to reformulate her identity, it did not translate to enacting her identity as a fun mathematics teacher.

\subsubsection{Contributing Factors on Jackie's Identity Development}

Jackie strongly wanted to become a mathematics teacher who teaches mathematics in a fun way. She set this direction during the mathematics methods course and wanted to practice the designated identity to become a fun mathematics teacher. However, her designated identity was not strongly reinforced during student teaching as we document in the following.

Firstly, we discuss the degree to which the vision of teaching mathematics was shared with her mentor teacher. In Mr. Brown's 5th grade classroom, Jackie did not share her goal of making mathematics fun with her mentor teacher. Jackie was engaged with specific mathematics knowledge and skills from her mentor teacher, but it focused on problem solving, multiple methods, and asking questions that promote students' mathematical understanding. These are important teaching practices, consistent with the university methods course, and valued in reformed mathematics teaching, but this was not what Jackie wanted to practice to become a fun mathematics teacher. In other words, Jackie's emerging identity was not fully supported by Mr. Brown. Thus, Jackie had limited opportunities to observe the modeled teaching practice that aligned to her designated identity. While engaging with the above characterized practices, Jackie, a novice teacher, had to interpret the master's teaching practice and negotiate what to adopt from her mentor, what not to adopt, and how to balance teaching from moment to moment. As a novice teacher, she was being apprenticed to knowledge and skills needed through participation in a community focused on teaching for understanding, in real-world contexts, rather than through hands-on activities.

Another factor is the importance of opportunity to teach. Jackie attempted to practice fun mathematics, but it was not successful. This may be because Jackie entered the mathematics methods class with limited content knowledge, which directly resulted in her lack of confidence in mathematics and lack of participation. The lack of participation brought the lack of opportunity to teach and it kept her from practicing her designated identity to be enacted. Lave and Wenger (1998) argue that opportunity to practice is central because preservice teachers' learning occurs when they increase their participation in their community of practice. To be a master teacher, who is knowledgeable about the required skill, it is necessary to participate in doing and trying out the tasks she or he is attempting to teach

Lastly, the level of feedback given by her mentor teacher was also important. Mr. Brown called that he learned content from colleges and learned more about what teaching is really about from his own student teaching. Based on his experience, he focused his feedback on general pedagogical support rather than on providing content-specific feedback. This may be due to his mathematical background, since he was confident in his mathematics knowledge. While general pedagogical feedback is certainly very helpful for preservice teachers, it seems that Jackie also needed content-specific support and feedback from Mr. Brown, especially focused on teaching mathematics for understanding. Jackie commented that she was dependent on him and needed extra help, especially with mathematics because it was the hardest subject for her to teach. Even though Jackie was provided with feedback from her mentor teacher, she still lacked specific feedback with respect to the mathematics content and instruction that she wanted to practice. This seemed to hinder her ability to incorporate pedagogical skills and limited her in practicing her identity as a fun mathematics teacher.

\subsection{Meg's Identity}

\subsubsection{Meg's Incoming Identity Brought to Mathematics Methods Course}

Meg's K-12 experiences with mathematics contrasted with Jackie. Meg recounted that mathematics was always her favorite subject. She expressed her confidence in doing mathematics by sharing that she was always one of the top students in class. However, one common experience that both Jackie and Meg shared was that they learned mathematics quite traditionally. However, what is interesting from Meg's statement is how she framed traditional mathematics teachers. Drawing on her experience, she characterized the teachers who did not help 
students understand as traditional and those teachers that did support conceptual understanding as reform. Meg recalled one middle school algebra teacher as the "best" mathematics teacher because Meg understood algebra very well, even though her teacher algebra using lots of worksheets. This implies that Meg's placed an emphasis on teaching mathematics for conceptual understanding. Thus, based on her K-12 school experience, Meg's mathematical identity was traditional because she rarely engaged with conceptual understanding, but despite this, she generally had a positive experience learning mathematics. Similar to Jackie, Meg's traditional incoming identity was reconstructed during the mathematics methods course.

Meg recalled that the methods course was very different from how she was taught. Meg said she could not remember ever using manipulations as a student and she was surprised by the way the methods instructor used hands-on materials to teach many mathematics topics conceptually. She stated: This is what I learned from her class. She would teach us ways to do elementary math that I never learned as a kid. For example, I never thought about the meaning of division or multiplication before, never thought about it that way, what I did was just memorization. So after all these years, I understand the concept and it almost clicked for me like "oh, that is what I am supposed to be learning". I think it is a bad sign that you can't get a click this far in life. (Meg's 1st interview)

This was an eye opening experience for her, because Meg learned multiplication solely through rote memorization. Meg further stated that it is unfortunate that students do not really understand what they learned in elementary school until they attend college. Meg repeated how much she was impressed by how the class focused on conceptual understanding in learning mathematics. Her experience in the mathematics methods class was characterized in two ways: 1) as a contrasting experience from the way she learned in K-12, and 2) confirming the importance of teaching mathematics conceptually. Thus, through her participation in the mathematics methods course, Meg developed her designated identity as a mathematics teacher who teaches mathematics conceptually.

\subsubsection{Student Teaching: Meg's Emerging Identity in the Community of Practice}

After the mathematics methods class, Meg was placed in a 1st/2nd combination classroom. Mrs. Green, her mentor teacher, was a veteran teacher who had been teaching mainly Kindergarten and 1st grade for more than 20 years. Unlike Mr. Brown, Mrs. Green stated that she is now comfortable teaching mathematics after much effort, but mathematics had not been an easy subject to teach due to her experiences as a learner of mathematics.

One salient feature of this classroom was that Mrs. Green handed over the math class to Meg from the beginning of the semester. Mrs. Green allowed Meg to teach the mathematics lesson by herself as long as it covered the district standards. This obviously contrasts with Jackie's case. During the entire semester, Meg taught the majority of mathematics lessons. Even though Meg had plenty of opportunity to teach mathematics, the data analysis still shows that Meg's emerging identity was not practiced much in this community of practice, as we detail below.

When Meg was told to teach $20 \div 4$, instead of using the worksheet that Mrs. Green provided, Meg introduced the concept through fair sharing. She drew 20 candies and 4 students using the smart board and demonstrated equal sharing. She then posed two more word problems and had students solve them, which most students did successfully. This episode showed that Meg carved out space to practice the type of mathematics teaching that she wanted to do during the semester. With the success of this lesson, she gained enough respect from Mrs. Green to continue practicing the form of teaching that she learned in the method course. Additionally, the successful delivery of the lesson gave Meg the confidence to continue what she wanted to do. In alignment with her designated identity of teaching mathematics conceptually, she taught mathematics to introduce concepts rather than teaching algorithms. However, during her teaching, she focused more on the process of deliver rather than checking students' conceptual understanding. For example, during this lesson, Meg did not ask why or how questions to check students' understanding, invite the students to explain their thinking, or ask for their problem solving strategies. Rather, she focused on telling the students what to do before moving to the next problem based on the answers without further justification, which was consistent with the mathematics norms established by Mrs. Green. As a novice teacher, Meg tried to teach mathematics conceptually and provided visual representations to teach concepts. However, support for higher order thinking questions and pressing for justifications that enhance conceptual understanding was not provided. Meg attempted to adopt the method course instructor's teaching methods to align with her designated identity, but she did not have enough knowledge or skill of how to teach mathematics conceptually. In sum, during student teaching, Meg's identity as a conceptual mathematics teacher was reinforced more than Jackie through ample practice, but it was still limited. 


\subsubsection{Contributing Factors on Meg's Identity Development}

In the earlier section, we discussed three aspects as contributing factors to the identity development of Jackie-shared vision, opportunity to teach, and meaningful feedback. Meg's case also highlighted these three as important factors.

Firstly, classroom observations and interview data showed that Meg's vision of teaching mathematics with an emphasis on conceptual understanding contrasted with Mrs. Green's community of practice. Mrs. Green's teaching practice emphasized drill, practice, and worksheets as she stated that traditional mathematics teaching, using timed tests and worksheets, were better for students to achieve on standardized tests. Similar to Jackie, such contrasting visions limited Meg's opportunity to observe conceptual teaching of mathematics modeled by her mentor.

Secondly, with respect to the opportunity to teach, Meg's participation in teaching mathematics was much more extensive than that of Jackie's. Unlike many preservice teachers and mentor relationships, Meg took over the teacher's role from the beginning of the semester in mathematics. Early on, her role was similar to a full time teacher and her mentor's role was supplementary in terms of teaching mathematics. Meg reflected that such teaching opportunities helped her not to fall back to the traditional methods and to become more confident as a mathematics teacher. However, Meg's teaching example of $20 \div 4$ described above shows that teaching mathematics conceptually was not fully successful in this community of practice because Meg did not fully understand how to implement conceptual mathematics instruction. Plenty of opportunity to teach and central participation were helpful to practice her identity, but it was not enough to reinforce Meg's identity.

Thirdly, Meg's case strongly highlighted the importance of meaningful feedback. Despite the contrasting vision of teaching mathematics, Meg preserved her prior goals of teaching mathematics conceptually and had many opportunities to practice. However, as teaching mathematics conceptually involved new skills and pedagogy, Meg needed to have meaningful feedback and guidance to improve her teaching practice. As conceptual understanding involved different teaching skills than what Mrs. Green had developed, Meg had limited opportunities to have her desired teaching practices modeled for her and to receive meaningful feedback about how to shift her own teaching of mathematics to be more conceptual. Thus, Meg was limited in developing as a teacher in alignment with her emerging identity. In sum, during student teaching, Meg's identity as a mathematics teacher was reinforced through ample practice, but it was limited by a lack of feedback focused on her identity.

\section{Discussion}

The cases of Jackie and Meg reveal identity development of teachers to be a complex process extending across K-12 learning experiences, methods courses, and student teaching. In Jackie's case, she had what many mathematics educators hope for, a mathematics methods class focused on conceptual understanding and a student teaching placement aligned to the class. However, Jackie struggled to develop her practice during her student teaching experience. Her identity development was limited due to her lack of confidence, limited grasp of teaching for understanding, limited opportunities to practice, and lack of detailed feedback. Unlike Jackie, Meg was a confident preservice teacher who wanted to adopt teaching mathematics for understanding and had ample opportunities to practice her identity. However, an expert not aligned with her developing identity did not reinforce her goals. Therefore, while Meg had the confidence and space to practice her identity, she did not receive specific feedback to further develop her goal of focusing on conceptual mathematics.

Not surprisingly, the findings provide evidence that preservice teachers' prior mathematics experiences contributed to their identities, both in terms of their mathematics knowledge and confidence. Jackie did not have a positive relationship with mathematics during her early school years and shifted her identity in coursework to wanting to become a fun mathematics teacher. Yet, her lack of knowledge and confidence limited her participation and ability to take on more central practices and her identity of a fun mathematics teacher remained superficial. On the contrary, one of the important reasons that Meg developed her mathematics identity further was her confidence and conceptual mathematics knowledge. When the opportunity was given, Meg did not hesitate to try new practices aligned with her emerging identity. The mathematics methods course positioned both Jackie and Meg to focus on teaching mathematics for understanding. Past experiences with mathematics seemed to influence teachers' identities through confidence and knowledge, which served to support or hinder further development.

While prior experiences affected identity development, various aspects of their relationships with mentor teachers also played a role. Specifically, opportunity to teach, quality of feedback, and the alignment of preservice teacher and mentor teacher goals impacted their emerging identities. The opportunity to teach that 
Mrs. Green allowed Meg is supported by scholars who argue that engaging preservice teachers in authentic teaching tasks (Ball \& Cohen, 1999), as opposed to pseudo-teaching situations (Feiman-Nemser \& Buchmann, 1989), is critical for preservice teachers to develop knowledge and skills to develop as teachers. Relationships with mentors played a critical role in determining preservice teachers' opportunities to practice in this study. More central participation was possible for Meg because Mrs. Green's mentoring style allowed a high level of autonomy. On the contrary, Jackie resisted taking on the opportunity to practice. However, Mr. Brown did not push her to move out of her comfort zone either. Regardless of the level of autonomy, both preservice teachers stated that they wanted to respect their mentor's teaching style because it was her or his class. This implies that preservice teachers had to negotiate between what they wanted to try and what was already given to them, how much they want to push in terms of their desired identity, or how much they accepted the given culture. This negotiation has clear implications for the space preservice teachers have to further develop their identities. This requires mentors to be responsive to what preservice teachers bring with them to the classroom.

Another critical issue was the alignment of preservice and mentor teacher goals for mathematics instruction. There is a prevalent belief that mentor teachers are supposed to serve as role models for preservice teachers and that preservice teachers should emulate mentor teachers' teaching practices (Wang \& Odell, 2007). Ronfeld and Grossman (2008) noted that it is difficult for preservice teachers to reconcile their emerging identity when the mentor teacher does not share the same goals about what it means to become a mathematics teacher. The cases of Meg and Mrs. Green are examples of this. While Meg developed more towards her desired mathematics teaching identity than Jackie, Mrs. Green built a close relationship with Meg and greatly supported her in establishing classroom management skills in addition to providing an extensive amount of teaching practice. Interestingly, time to practice mattered, possibly even more than alignment between their goals. However, the relationship is complex because Mrs. Green's mathematics teaching practice was not parallel with the teaching pedagogy that Meg was developing. This limited the type of feedback that Mrs. Green could provide in terms of questioning strategies, focusing on student explanations, and how to support multiple strategies in the classroom.

Feedback is critical as preservice teachers attempt to develop their mathematics teaching identities. Feedback can hone their practices and, thus, challenge or shape their developing identity. The preservice teachers in this study stated that they revised or followed the lesson plan depending on the mentor's feedback; they considered their mentor's feedback important in their teaching, even when it did not align with their desired identity. It calls attention to the need for understanding the types of feedback mentor teachers provide. In terms of the type of feedback, this is intimately linked to the type of practice mentor teachers have developed. Do they have detailed knowledge of questioning for understanding, adapting the curriculum, or assessing student thinking? Depending on their own identity, they will facilitate different kinds of identity development from their preservice teachers.

The findings of study also raise the issue of training for mentors. Further study is needed to be able to understand how to support mentors to provide feedback; when is the best time to provide feedback? What are the major foci of the feedback such as pedagogical content knowledge, including questioning, content specific feedback, and feedback about vision of teaching mathematics? Our finding also demonstrates that the mentors' role is critical in preservice teachers' learning to teach and their identity development. However, we still do not understand long-term effects of mentoring (Evertson \& Smithey, 2000) on teachers' identity formation. One suggestion is to research various types of student-mentor relationships, such as Jackie with a mentor who pushes her to teach, or Meg with a mentor who fits her needs. This will help the field better understand how to place preservice teachers in mentor's classrooms in order to maximize learning experiences.

\section{Conclusion}

The identity development of preservice teachers is a complex space to understand. Sometimes we oversimplify preservice teacher identity as a battle between procedural mathematics in their prior learning and conceptual mathematics developed in teacher education. Instead, we have attempted to portray identity development as an ongoing process that is affected by multiple factors. Some of these factors include experiences, knowledge, and confidence developed prior to teacher education, while others develop during teacher education, either through coursework or field experiences. Their relationship with mentor teachers is a critical aspect of becoming a mathematics teacher, but the field often discusses alignment of teaching goals between preservice and cooperating teachers alone. While this is important, time to practice, type of feedback, and timing of feedback may be just as important.

However, further study is needed to better understand how to support the identity development of preservice mathematics teachers during their methods courses and student teaching. It may be that providing more time for activities such as rehearsals or microteaching in teacher education may be a way to add practice time under 
supervision of the methods instructor. Additionally, understanding more about dynamics during student teaching such as time to practice, alignment of instructional goals, and different types and timing of feedback, can help the field better understand how to support preservice teachers in developing their mathematics teaching practice. Understanding more detail about factors influencing teachers' identity can only help us understand more about improving teacher preparation in mathematics.

\section{References}

Ball, D. L., \& Cohen, D. (1999). Developing practice, developing practitioners: Toward a practice-based theory or professional practice. In L. Darling Hammond, \& G. Sykes (Eds.), Teaching as the learning profession: Handbook of policy and practice (pp. 3-32). San Francisco: Jossey-Bass.

Bullough, R. V. (1992). Beginning teacher curriculum decision making, personal teaching metaphors, and teacher education. Teaching and Teaching Education, 8(3), 239-252. https://doi.org/10.1016/0742-051X(92)90023-V

Cady, J., Meier, S. L., \& Lubinski, C. A. (2006). Developing mathematics teachers: The transition from preservice to experienced teacher. The Journal of Educational Research, 26, 295-305. https://doi.org/10.3200/JOER.99.5.295-306

Drake, C. (2006). Turning points: Using teachers' mathematics life stories to understand the implementation of mathematics education reform. Journal of Mathematics Teacher Education, 9, 579-608. https://doi.org/10.1007/s10857-006-9021-9

Drake, C., Spillane, J., \& Hufferd-Ackles, K. (2001). Storied identities: teacher learning and subject-matter context. Curriculum Studies, 33(1), 1-23. https://doi.org/10.1080/00220270119765

Ebby, C. B. (2000). Learning to teach mathematics differently: The interaction between coursework and field work for preservice teachers. Journal of Mathematics Teacher Education, 3, 69-97. https://doi.org/10.1023/A:1009969527157

Eisenhart, M., Borko, H., Underhill, R., Brown, C., Jones, D., \& Agard, P. (1993). Conceptual knowledge falls through the cracks: Complexity of learning to teach mathematics for understanding. Journal for Research in Mathematics education, 24, 8-40. https://doi.org/10.2307/749384

Enyedy, N., Goldberg, J., \& Welsh, K. M. (2005). Complex dilemmas of identity and practice. Science Education, 90(1), 68-93. https://doi.org/10.1002/sce.20096

Evertson, C. M., \& Smithey, M. W. (2000). Mentoring effects on protégés' classroom practice: An experimental field study. Journal of Educational Research, 93(5), 294-304. https://doi.org/10.1080/00220670009598721

Feiman-Nemser, S. (2001). Helping novices learn to teach: Lesson from an exemplary support teacher. Journal of Teacher Education, 52(1), 17-30. https://doi.org/10.1177/0022487101052001003

Feiman-Nemser, S., \& Buchmann, M. (1989). Describing teacher education: A framework and illustrative findings from a longitudinal study of six students. Elementary School Journal, 89, 365-377. https://doi.org/10.1086/461580

Graven, M. (2004). Investigating mathematics teacher learning within an in-service community of practice: The centrality of confidence. Education Studies in Mathematics, 57(2), 177-211. https://doi.org/10.1023/B:EDUC.0000049277.40453.4b

Hamman, D., Gosselin, K., Romano, J., \& Bunuan, R. (2010). Using possible-selves theory to understand the identity development of new teachers. Teaching and Teacher Education, 26, 1349-1361. https://doi.org/10.1016/j.tate.2010.03.005

Hawkey, K. (1998) Mentor pedagogy and student teacher professional development: a study of two mentoring relationships. Teaching and Teacher Education, 14(6), 657-670. https://doi.org/10.1016/S0742-051X(98)00015-8

Hodgen, J., \& Askek, M. (2007). Emotion, identity and teacher learning: becoming a primary mathematics teacher. Oxford Review of Education, 33 (4), 469-487. https://doi.org/10.1080/03054980701451090

Holland, D., \& Lave, J. (Eds.). (2001). History in person: Enduring struggles, contentious practice, intimate identities. Santa Fe, NM: School of American Research Press; Oxford, UK: James Currey.

Holland, D., Lachicotte, W. J., Skinner, D., \& Cain, C. (1998). Identity and agency in cultural worlds. Cambridge, MA: Harvard University Press. 
Horn, I. S., Nolen, S. B., Ward, C., \& Campbell, S. S. (2008). Developing practices in multiple words: The role of identity in learning to teach. Teacher Education Quarterly, 61-72.

Kagan, D. M. (1992). Professional growth among preservice and beginning teachers. Review of Educational Research, 62, 129-169. https://doi.org/10.3102/00346543062002129

Kilgore, D. W. (1990). Understanding learning in social movements: a theory of collective learning. International Journal of Lifelong Education, 19(3), 191-202.

Lave, J. \& Wenger, E. (1991). Situated learning: Legitimate peripheral participation. New York: Cambridge University Press. https://doi.org/10.1017/CBO9780511815355

McDiarmid, G. W. (1990). Challenging prospective teachers' beliefs during early field experience: A quixotic undertaking? Journal of Teacher Education, 41(3), 12-20. https://doi.org/10.1177/002248719004100303

Mewborn, D. S. (1999). Learning to teach elementary mathematics: ecological elements of a field experience. Journal of Mathematics Teacher Education, 3, 27-46. https://doi.org/10.1023/A:1009925728974

Miles, M. B., \& Huberman, A. M. (1994). Qualitative data analysis: An expanded sourcebook. Thousand Oaks, CA: Sage.

Ronfeldt, M. \& Grossman, P. (2008). Becoming a professional: experimenting with possible selves in professional preparation. Teacher Education Quarterly, 35, 41-60.

Senk, S. L., \& Thompson, D. R. (Eds.) (2003). Standards-based school mathematics curricula: What are they? What do students learn? Mahwah: Erlbaum.

Sfard, A., \& Prusak, A. (2005). Telling identities: In search of an analytic tool for investigating learning as a $\begin{array}{lllll}\text { culturally shaped activity. Educational Researcher, 34(4), 14-22. } & \text {. }\end{array}$ https://doi.org/10.3102/0013189X034004014

Steele, D. F. (2001). The interfacing of preservice and inservice experiences for reform-based teaching: A longitudinal study. Journal of Mathematics Teacher Education, 4, 139-172. https://doi.org/10.1023/A:1011436116480

Sumara, D. J., \& Luce-Kapler, R. (1996). (Un) Becoming a teacher: negotiating identities while learning to teach Canadian Journal of Education, 21(1), 65-83. https://doi.org/10.2307/1495065

Wang, J., \& Odell, S. J. (2007). An alternative conception of mentor-novice relationships: Learning to teach in reform-minded ways as a context. Teaching and Teacher Education, 23, 473-489. https://doi.org/10.1016/j.tate.2006.12.010

Wenger, E. (1998). Communities of practice: Learning, meaning and identity. Cambridge, UK: Cambridge University Press. https://doi.org/10.1017/CBO9780511803932

Yin, R. K. (1995). The art of case study research. Thousand Oaks, CA: Sage.

Note

Note 1. All names are pseudonym.

\section{Copyrights}

Copyright for this article is retained by the author(s), with first publication rights granted to the journal.

This is an open-access article distributed under the terms and conditions of the Creative Commons Attribution license (http://creativecommons.org/licenses/by/4.0/). 